DOI:10.1093/esr/jcq011

\title{
Moral Communities? Religion as a Source of Social Trust in a Multilevel Analysis of 97 German Regions
}

\author{
Richard Traunmüller
}

\begin{abstract}
This contribution examines the role of religion as source of social trust. Going beyond the scope of the existing literature, we jointly evaluate the effect of individual religiosity and regional religious context by means of multilevel analysis of 97 small-scale German regions. The results based on the German Socio-Economic Panel suggest that there is a double positive effect of Protestantism: Not only do Protestants tend to be more trusting, but a Protestant context also increases one's trust-regardless of individual religious beliefs. Conversely, social trust is less developed in Catholic-dominated regions. In addition, although Catholic individuals are more trusting than the non-religious individuals, they do not differ from members of smaller Christian groups or Muslims. At same time, the notion that certain religious groups and especially religious minorities are distrustful of the wider society is not substantiated by empirical evidence. Furthermore, while church attendance is a powerful predictor for social trust, a context effect for regional levels of devoutness could not be detected. Finally, religious diversity decreases social trust for Muslims only, but not to a degree as to pose a threat to social integration.
\end{abstract}

\section{Introduction}

The idea of religion as an important resource for social cohesion has long been a staple in the social sciences, dating back to the writings of Tocqueville ([1862] 1954) and Durkheim ([1897] 1951, [1912] 1995). Recently, this idea has resurfaced within social capital theory. From its inception, the focus on social capital has indeed been linked to thoughts on religion. Coleman (1988; Coleman and Hoffer, 1987), for instance, observes that it is the close interconnection between the school, parents, and the religious community that enables private Catholic schools to teach more effectively and keep students from dropping out, as compared to public or secular private schools. In his study on social capital in the US, Putnam (2000) finds that the most common form of associational membership is religious in nature and that individual religiosity rivals education as the most important explanatory factor for social capital endowment. Finally, Fukuyama (1995, 1999, 2000) stresses the role of Protestant norms and values for a culture of trust that extends social trust from close kin to people in general and contrasts them with the distrustful familism inherent in Confucianism or Catholicism. In the last couple of years, religion has also received more systematic consideration in empirical social capital research (Smidt, 2003). The present paper aims to 
contribute to this emerging debate in three important ways, which are detailed in the following.

First, the literature so far has concentrated on the impact of religion on organizational membership and civic engagement (Becker and Dhingra, 2001; Campbell and Yonish, 2003; Greeley, 1997; Lam, 2002, 2006; Putnam, 2000; Ruiter and De Graaf, 2006; Smidt, 1999; Park and Smith, 2000; Uslaner, 2002a; Wilson and Janoski, 1995; Wuthnow, 1999). While results differ in details, the common theme is that religion has a positive effect on both associational membership and civic engagement, thus contributing to the common good.

Much less attention, however, has been given to religion's influence on another equally important form of social capital, namely social trust (see Norris and Inglehart, 2004; Welch et al., 2004). Generalized social trust is widely regarded as being a crucial cultural aspect of social capital, as it taps an individual's affective relation to the wider society and facilitates cooperation between people by reducing transaction costs (Freitag and Traunmüller, 2009; Fukuyama, 1995; Putnam, 2000; Stolle, 2002; Uslaner, 2002b). In this paper, the existing literature is expanded upon by focusing on the role of religion in the formation of social trust.

Second, with the notable exception of a handful of comparative studies (e.g. Bahovec et al., 2007; Halman and Petterson, 2003; Lam, 2006; Ruiter and De Graaf, 2006) as well as singular case studies for Finland (Yeung, 2004), Germany (Traunmüller, 2009), and the Netherlands (De Hart, 2001), empirical analyses that focus explicitly on the impact of religion on social capital are very much restricted to North America. Since the USA is widely regarded as being an exceptional case when it comes to matters of religious life, it is beyond doubt that researchers should move beyond North America and explore the generalizability of religion's influence on social capital in other cultural contexts (Roßteutscher, 2009).

In this analysis, we focus on Germany whose religious landscape is markedly different from that of the US. Traditionally, Germany is a confessionally mixed country with a Protestant majority and a large Catholic minority. Since unification with the former German Democratic Republic (GDR), where enforced secularization by the socialist regime has led to a widespread and enduring loss of religiosity (Meulemann, 2004), contemporary Germany is nearly equally split between three groups, i.e. Catholics, Protestants, and the non-religious. Moreover, due to immigration, Germany now has a growing Muslim minority which not only contributes to the diversity of religious life but also poses new challenges to social integration. Taken together, these aspects make Germany a most interesting case for the differentiated study of religion's impact on social capital formation that may also be more indicative of other European societies.

Third, research so far has mainly focused on individual religiosity and its impact on social capital. However, religiosity is also a property of whole collectives and thus constitutes the structural as well as cultural context in which individual social capital formation takes place (cf. Finke and Adamczyk, 2008; Kotler-Berkowitz, 2001). To be certain, some macro quantitative comparisons based on aggregated data include variables on religion in their models (e.g. Bjørnskov, 2006; Delhey and Newton, 2005), but individual and contextual effects are usually confounded in these studies. Up to now, there have only been very few attempts to actually separate individual from contextual effects by considering them simultaneously in multilevel applications (Ruiter and De Graaf, 2006; Lam, 2006; Borgonovi, 2008).

Therefore, on the methodological side, we go beyond the scope of the existing literature by jointly evaluating the effect of individual religiosity and regional religious context using multilevel analysis. Relying on survey data from the German Socio-economic Panel (GSOEP), 97 sub-national contexts in Germany, namely the German Raumordnungsregionen, are compared. The regions of small scale may be theoretically better suited for analyzing context effects as compared to whole nations, since they constitute the immediate social surrounding of individuals (cf. Borgonovi, 2008). The regions considered in the present paper are functionally confined units that are located between the regional levels of NUTS 2 and NUTS 3. Therefore, it is quite plausible to assume that for most people, home, workplace, as well as places for leisure are all located within the same region (Legewie, 2008).

The sub-national perspective further eliminates some of the methodological problems frequently encountered in the comparison of whole nations (Snyder, 2001). For instance, this research strategy allows for a controlled comparison between units by holding other influential factors constant. In particular, the confounding effects of religious traditions and political institutions on social trust (Delhey and Newton, 2005) are elegantly disentangled in our case by holding the latter constant. In this sense, the present analysis meets the requirements of a most similar systems research design in an optimal way (Lijphart, 1971; Przeworski and Teune, 1970). Finally, scaling down to the level of 
regions is an effective way to increase one's number of cases. This circumvents the common problem of being able to only include a limited number of level-2 variables due to small sample size at the contextual level.

The organization of the remainder of this paper is straightforward. In a first step, we introduce theoretical arguments from the literature and derive testable hypotheses on how both individual religiosity and religious context may impact on the formation of social trust. In a second step, we address data and measurement issues. In the third step, individual and context hypotheses are empirically tested by means of multilevel analysis. Finally, results are discussed in the conclusion.

\section{Religion and Social Trust: Theory and Hypotheses}

\section{Individual-Level Hypotheses}

In the literature, there are two general explanations of why individual religiosity should encourage social capital formation (Leege, 1993; Putnam, 2000; Smidt, 2003; Traunmüller, 2009; Wuthnow, 1990). The first perspective views religiosity primarily as a cultural phenomenon, thereby stressing the effects of religious beliefs, norms, identities, and worldviews. The second perspective focuses on structural aspects of religiosity and thus on the effects that result from social integration and active participation in religious communities.

\section{Religious group identity hypothesis}

Since social trust has an important foundation in moral beliefs and views of human nature (Uslaner, 2002b; Wrightsman, 1992), different religious identities may explain variations in individuals' propensity to place trust in others. Generalized social trust rests on the perception that most people are part of the same 'moral community' (Uslaner, 2002b: 26). Therefore, inclusive religious group identities that advance doctrines of common grace, human potential, and goodness will encourage their adherents to be trusting (Welch et al,, 2004). In Germany, these positive and inclusive views are most likely endorsed by majority religious traditions that are well integrated in the wider society, i.e. Protestantism and Catholicism.

However, religiosity may also lead to distrust of other people. In fact, conservative religious groups are often used to epitomize the 'dark side' of bonding social capital, where high in-group trust goes hand in hand with intolerance, prejudice, and distrust toward out-groups (Roßteutscher, 2008). This should be particularly the case for rigid religious groups whose view on human nature is pervaded by ideas of sinfulness and whose identity is based on strong symbolic boundaries between believers and nonbelievers, members of the religious in-group and the rest of society (Welch et al., 2004). Distrust may therefore be an attribute of fundamentalist or evangelical Protestants and other Christian sects. In addition, with regard to Islam, it is also plausible to assume that members of the Muslim minority define themselves through a symbolic demarcation from the majority and therefore are less trusting of people in general. Of course, the distrust of religious minorities may also be due to the perceived or actual discrimination of one's own religious group by the majority society. Therefore, we hypothesize:

H1: Catholics and Protestants will be more trusting than members of small Christian sects and adherents of Islam.

\section{Religious network hypothesis}

In addition to cultural aspects of individual religiosity, much of the following literature stresses the structural side of religious life and its distinct effect on social capital accumulation: '[S]ocial ties embodied in religious communities are at least as important as religious beliefs' (Putnam, 2000, 67). Trust, according to Fukuyama, 'arises within a community of regular, honest, and cooperative behavior, based on commonly shared norms' (1995: 26f). The congregation is such a community where people from different segments of society meet face to face on a regular basis and come to know one another as like-minded, benevolent, and cooperative. This trustworthy behavior is further reinforced by reputational effects that arise from regular interaction with other church members and the density of connections between congregants (Buskens and Raub, 2002; Coleman, 1988; Cook and Hardin, 2001). Interactions within a religious group are therefore usually characterized by trust, as well as frequently by trust that is met, returned, or reciprocated, thereby providing a suitable training ground for a generalized propensity to trust (Sztompka, 1999, 131). This leads to hypothesize that:

H2a: People who attend religious services on a regular basis express greater social trust in people than the religiously un-involved. 
Of course, religious traditions may differ in their potential to generate social trust depending on their respective organizational structure (Putnam, 1993; Roßteutscher, 2009; Verba et al., 1995). In particular, the egalitarian and horizontal network structure of Protestant congregations and smaller Christian groups should be more conducive to the formation of mutual trust than the hierarchical structure of the Catholic Church (Putnam, 1993). With regard to Islam, it is also sometimes argued that it is a hierarchical religion detrimental to social trust (e.g. Guiso et al., 2003; LaPorta et al., 1997). However, this assumption is not very plausible given the fact that Muslim congregations indeed tend to be horizontally organized (Gellner, 1981). Accordingly, the hypothesis reads:

$\mathrm{H} 2 \mathrm{~b}$ : The positive effect of religious service attendance on social trust will be stronger for Protestants, members of small Christian groups, and Muslims than for Catholics.

\section{Contextual-Level Hypotheses}

Religiosity is not only a property of individuals but also of collectives. The religiosity of a collective serves as a cultural as well as structural context for individuals and is therefore likely to have an impact on social trust independent from individual religiosity (Finke and Adamczyk, 2008; Kotler-Berkovitz, 2001; Stark and Bainbridge 1996). In the following, we consider three such aspects of religious context and their impact on individual-level social capital formation: the dominant religious cultural tradition in a given region, overall levels of devoutness, and the degree of religious diversity.

\section{Religious culture hypothesis}

An influential line of thought stresses the role that religious traditions play for the culture and social life in a given nation or region (Eisenstadt, 2000; Fukuyama, 1995; Inglehart and Baker, 2000; Norris and Inglehart, 2004; Weber, [1920] 1988). According to this perspective, distinctive worldviews that were historically linked with or once originated from religious traditions have left deep imprints on contemporary moral beliefs, social norms, and interpersonal attitudes (Inglehart and Baker, 2000). In contrast to individual religious beliefs, these values are now part of the general culture and are shared by most of the citizens in a given region-regardless of whether they consider themselves to be religious or not. As Germany is a confessionally mixed country with a (primarily) dominant religious tradition of Protestantism in the north and a dominant culture of Catholicism in the south, there should, according to the religious culture thesis, be clear cultural differences across the respective regions that are evident even today.

One fundamental cultural consequence of a Protestant tradition lies in its inherent imperative to extend virtues such as truth-telling, reliability, and reciprocity beyond the narrow circle of one's own family (Fukuyama, 1995; Weber, [1920] 1988). In regions dominated by Protestants, more people would have internalized these norms and thus behave in honest and trustworthy ways when dealing with strangers. This leads to more positive experiences in everyday interactions and encourages the extension of trust to people in general, including strangers. A region's Protestant legacy will thus result in a pronounced contemporary culture of trust. Catholicism, on the other hand, might be conducive to an 'amoral familism' (Banfield, 1958), i.e. a cultural trait where moral behavior is only exhibited toward the own in-group but not toward people in general. In regions with high percentage of Catholic population, social interactions between strangers will therefore entail less experiences of trustworthiness. The development of trust in a given population could therefore be impeded by its Catholic heritage (Fukuyama, 1995; Putnam, 1993). Indeed, several studies show that, in international comparison, countries with a Protestant traditional background display the highest levels of social trust, whereas Catholic nations score rather low on trust measures (e.g. Bjørnskov, 2007; Delhey and Netwon, 2005; Inglehart and Baker, 2000). Transferring this argument to the German regions, we hypothesize that:

H3: In regions with Protestant tradition, people will be more trusting, while in Catholic-dominated regions people will display lower levels of trust.

\section{Social control hypothesis}

A central claim of social capital theory is that social networks also have external effects and therefore constitute public goods, i.e. they also influence and benefit people in the broader community who are not part of and/or do not contribute to the network themselves (Coleman, 1988; Putnam, 2000). Accordingly, one would not only expect effects from individual religious involvement and church attendance, but also from the general levels of devoutness and church going within a given region (Ruiter and De Graaf, 2006). In other words, regional church attendance rates serve as structural contexts that may impact the social trust of both religious and secular people.

An important external effect of dense social networks that encourages the development of social trust 
is that they facilitate the sanctioning of social norms and the exercise of social control (Coleman, 1988; Cook and Hardin, 2001; Sampson, 2001). People who are highly involved in religious affairs and well integrated into a religious community are very likely to conform to pro-social norms and refrain from deviant acts and untrustworthy behaviors (Stark and Bainbridge, 1996). From this argument follows that in regions with high levels of devoutness more people will play by the rules and act in a trustworthy and cooperative way, than in regions where people lack such religious networks. A number of empirical studies at the individual and aggregate level corroborate this idea and find that religion tends to reduce many forms of social deviance (e.g. Baier and Wright, 2001; Bainbridge, 1989; Stark and Bainbridge, 1996; Stark, 1996).

Since deviant behavior will generally be lower in devout contexts with high levels of church attendance, all people living in these contexts-religious and secular alike-benefit from the maintenance of social order and are encouraged to trust one another. Thus, the hypothesis states that:

H4: In devout regions, people will display greater social trust, even if they themselves are not religious.

\section{Religious cleavage hypothesis}

Whereas the religious culture thesis stresses the shared cultural background of a region, the religious cleavage hypothesis focuses on religious differences and divisions and the potentially negative impact of religious diversity on the formation of social trust (Delhey and Newton, 2005; Gundelach and Traunmüller 2010). A classic assumption in the social sciences holds that social integration-and therefore the formation of social trust - is based on shared values that are thought to result from religious homogeneity (Parsons, 1967). Growing religious heterogeneity, which is primarily, but not exclusively due to immigrants from Islamic countries, may however lead to conflicts between religious groups and pose a potential threat to social connectedness (Casanova, 2006; Huntington, 1996; Wolf, 1999). Islam is sometimes perceived as an 'essentially anti-modern, fundamentalist, illiberal and un-democratic religion and culture' (Casanova, 2006, 12) whose moral concepts, values, beliefs, and attitudes are considered to be incompatible with those of the so-called Western world (cf. Gerhards, 2006; Norris and Inglehart, 2004).

The basic rationale behind the argument of the religious cleavage hypothesis is that people are more likely to connect with people who are like themselves and have many things in common (McPherson et al., 2001). Since social trust largely rests upon perceived similarities and a sense of familiarity, religious diversity may lead to a decrease in regional trust levels (Delhey and Newton, 2005; Gundelach and Traunmüller 2010). Indeed, several empirical studies suggest that greater ethnic heterogeneity seems to be associated with lower stocks of social capital (e.g. Alesina and La Ferrara, 2000; Anderson and Paskeviciute, 2006; Delhey and Newton, 2005; Putnam, 2007). We transfer this argument to religious heterogeneity of the German regions and hypothesize that:

H5: Greater religious diversity in a given region will lead to lower levels of social trust in its population.

\section{Data and Measurement}

In order to test the proposed hypotheses, we draw on survey data from the 2003 wave of the GSOEP. The aim of this project is to provide information on objective life conditions as well as subjective values and orientations by means of a representative longitudinal study of private households in Germany (Wagner et al., 2007). In contrast to many other survey projects, the large $N$ of the GSOEP allows for a reasonable analysis of religious minorities such as Muslims $(N=784)$ and smaller Christian groups and sects $(N=569)$. Another useful feature is the availability of the so-called Geocodes, which can be used to assign respondents to 97 small-scale regional units (Raumordnungsregionen). The resulting hierarchical data structure is suitable for multilevel analysis. The total sample size consists of $N=20.515$ individuals over the age of 16 who are nested in $N=97$ regions.

\section{The Dependent Variable}

Social trust is measured by a total of three survey items. On a scale from 'totally agree' (1) to 'totally disagree' (4), respondents were asked to respond to the following statements: On the whole one can trust people; nowadays one can't rely on anyone; and if one is dealing with strangers, it is better to be careful before one can trust them. The responses were rescaled so that higher values denote greater trust and then combined into a weighted index by means of factor analysis. As the indicator variables are ordinal, the factor analysis is based on a polychoric correlation matrix. The retrieved factor scores where multiplied by 100 in order to make the regression coefficients in the analyses better readable. 


\section{Explanatory Variables}

There are two explanatory variables at the individual level and three at the context level. At the individual level, religious group identity has five categories, distinguishing between 'non-religious' (0), 'Catholics' (1), 'Protestants' (2), 'other Christian groups and sects' (3), and 'Muslims' (4). Due to a small $N$, adherents of other non-Christian religions, such as Jews and Buddhists, had to be excluded from the analyses. For church attendance, a simple dummy variable was created, where 1 indicates regular church attendance 'at least once a month' and 0 'less often/never'. '

At the contextual level, a region's religious cultural tradition is measured by the percentage of Protestants and Catholics in the population, which was calculated by aggregating the individual level GSOEP data. ${ }^{2}$ Likewise, regional devoutness is measured by the regional population share that goes to church at least once a month. To capture religious diversity within a given region, we calculate a Herfindahl-Index based on the religious affiliation variable. ${ }^{3}$

\section{Controls}

In order to avoid spurious effects between the religion variables and social trust, several controls on both the individual and contextual levels are considered (cf. Freitag 2003; Freitag and Bühlmann, 2009; Freitag and Traunmüller, 2009; Delhey and Newton, 2005; Neller, 2008; Putnam, 2000; Uslaner, 2002b). At the individual level, we include respondents' sex, age, and age squared, as well as a dummy variable for foreign citizenship. The latter is expected to be associated with less social trust due to cultural differences or perceived discrimination (Uslaner, $2002 \mathrm{~b})$. A further important attribute in the German case, whether the respondent resided in East or West Germany prior to 1989 , was also considered. Not only did the experience of communism in the former GDR stimulate distrust in the political elite, but also among the citizens themselves (Sztompka, 1995). Since unification, these experiences have been relegated to the history books, but it is quite plausible that their imprint on the former East German consciousness has resulted in lingering low levels of generalized trust. Since higher-status people with more resources at their disposal in general are more trusting (Putnam, 2000), we also include a measure of household income and respondents' educational level, measured using the CASMIN classification (König et al., 1988). Finally, the core theorem of social capital theory suggests that social trust is generated in networks of civic engagement, where people learn to cooperate with each other and are socialized into pro-social values (Hooghe and Stolle, 2003; Putnam, 1993; Tocqueville, [1862] 1954). Therefore, we consider a dummy variable for organizational membership in the analyses.

At the contextual level, we include the regional gross domestic product (GDP) per capita (in thousand Euros) as first control variable, as levels of social trust tend to be higher under favorable economic conditions (Delhey and Newton, 2005). Some argue that urbanization leads to increased isolation of individuals and thus that low trust is likely to be found in big cities, whereas small communities should have high levels of trust (Putnam, 2000). Therefore, we also control for regional degree of urbanization measured as number of residents per square kilometer of settlement and traffic area. Furthermore, recent research on the contextual determinants of social trust has been focusing on the impact of political institutions (e.g. Freitag and Bühlmann, 2005, 2009; Neller, 2008) and on the effects of ethnic diversity (e.g. Bjørnskov, 2008; Hooghe et al., 2009; Putnam, 2007). Of course, in a sub-national comparison of small-scale regions, we cannot explicitly include political institutions as controls-rather they are held constant because they apply to all regions alike. Indeed, this is an important strength of the sub-national comparative method, which is particularly important in the context of religion and social trust as the effects of Protestantism and political institutions seem to be confounded at the national level (Delhey and Newton, 2005). With regard to ethnic diversity, we would argue that in Germany ethnic diversity is mainly defined in terms of religious diversity, which is a central theoretical and not a control variable in the present paper. Whereas in the United States debates on multiculturalism are widely determined by the racial cleavage between blacks and whites, in Europe, and especially in Germany, debates on immigration and multiculturalism focus on the challenges associated with Islam. However, we also control for a more general, non-religiously defined ethnic diversity by including a measure of the percentage of foreigners in a region. Higher shares of foreigners are expected to be associated with lower levels of social trust (Putnam, 2007). ${ }^{4}$

\section{Empirical Analysis}

To empirically test the individual and contextual level hypotheses, we employed multilevel analysis or hierarchical linear modeling (Gelman and Hill, 2007; Raudenbush and Bryk, 2002; Snijders and Bosker, 
1999) using the lmer package in R (Gelman and Hill 2007; R Project, 2000). All estimations are based on Residual Maximum Likelihood (REML). Furthermore, we have dealt with the problem of missing data by means of Multiple Imputation using the Amelia II package provided by King et al. (2001). In multiple imputation one imputes $m$ values for each missing cell in the data matrix and creates $m$ completed data sets. Since the rate of missingness was not very high (single variable values were missing for around $12 \%$ of the respondents), we imputed a total of $m=5$ data sets. Across these completed data sets, the observed values are the same, but the missing values are filled in with different imputations that reflect the uncertainty about the missing data. After imputation, each data set was analyzed separately and the results were then combined.

\section{Evidence at the Individual Level}

The first model specification is a simple random intercept model that includes only individual level predictors and controls, where the intercept is allowed to vary over regions (see Table 1). Looking at the coefficients in model $\mathrm{M} 1$, differences between religious identity groups seem to be rather small but can nonetheless be observed. Protestants show the highest trust levels, followed by Catholics, other Christians, and finally Muslims. In principle, these results are in accordance with the predictions of the religious belief hypothesis (H1). However, if we conduct a more formal test of group differences by changing around the reference categories (M2-M4), we find that Protestants are significantly more trusting than Catholics. Catholics in turn are more trusting than the non-religious, but in fact do not differ from members of smaller Christian groups or Muslims. Furthermore, while Protestants show the highest levels of social trust of all groups examined here, they are not significantly different from Christian minority groups and sects, who actually do not differ at all from any other religious identity group when it comes to social trust.

Viewed from another perspective, this of course indicates that, overall, there is no sign of mistrust of religious minorities-neither Muslim nor Christian-toward the society in general. Hypothesis $\mathrm{H} 1$ is therefore only partially supported.

Judging from the effect size of the coefficients, regular church attendance seems to be a more important factor for the formation of social trust than the

Table 1 Effects of individual religiosity on social trust (HLM)

\begin{tabular}{|c|c|c|c|c|c|c|c|c|}
\hline & \multicolumn{2}{|c|}{ M1 } & \multicolumn{2}{|c|}{ M2 } & \multicolumn{2}{|c|}{ M3 } & \multicolumn{2}{|c|}{ M4 } \\
\hline & Coef. & $t$-value & Coef. & $t$-value & Coef. & $t$-value & Coef. & $t$-value \\
\hline Intercept & $11.18^{*}$ & $(2.06)$ & $15.57^{\star *}$ & $(2.95)$ & $19.59^{* *}$ & $(3.74)$ & $13.33^{*}$ & $(2.09)$ \\
\hline Non-religious & \multicolumn{2}{|c|}{ Reference } & $-4.39^{*}$ & $(-2.33)$ & $-8.41^{* *}$ & $(-5.08)$ & -2.15 & $(-0.54)$ \\
\hline Catholic & $4.39^{*}$ & $(2.33)$ & \multicolumn{2}{|c|}{ Reference } & $-4.02^{*}$ & $(-2.49)$ & 2.25 & $(0.59)$ \\
\hline Protestant & $8.41^{* *}$ & $(5.08)$ & $4.02^{*}$ & $(2.49)$ & \multicolumn{2}{|c|}{ Reference } & 6.26 & $(1.63)$ \\
\hline Other Christian & 2.15 & $(0.54)$ & -2.25 & $(-0.59)$ & -6.26 & $(-1.63)$ & \multicolumn{2}{|c|}{ Reference } \\
\hline Muslim & 0.36 & $(0.09)$ & -4.04 & $(-1.09)$ & $-8.05^{*}$ & $(-2.12)$ & -1.79 & $(-0.39)$ \\
\hline Church attendance & $16.12^{* *}$ & $(7.64)$ & $16.12^{* *}$ & $(7.64)$ & $16.12^{* *}$ & $(7.64)$ & $16.12^{\star * x}$ & $(7.64)$ \\
\hline Sex & 1.50 & $(1.30)$ & 1.50 & $(1.30)$ & 1.50 & $(1.30)$ & 1.50 & $(1.30)$ \\
\hline Age & $-2.09^{* *}$ & $(-10.65)$ & $-2.09^{* *}$ & $(-10.65)$ & $-2.09^{* *}$ & $(-10.65)$ & $-2.09^{* *}$ & $(-10.65)$ \\
\hline $\mathrm{Age}^{2} / 10$ & $0.18^{* *}$ & $(10.20)$ & $0.18^{* *}$ & $(10.20)$ & $0.18^{* *}$ & $(10.20)$ & $0.18^{\star *}$ & $(10.20)$ \\
\hline East German & $-12.42^{* *}$ & $(-5.22)$ & $-12.42^{\star \star}$ & $(-5.22)$ & $-12.42^{* *}$ & $(-5.22)$ & $-12.42^{\star *}$ & $(-5.22)$ \\
\hline Foreigner & $-8.20^{\star *}$ & $(-3.12)$ & $-8.20^{* *}$ & $(-3.12)$ & $-8.20^{* *}$ & $(-3.12)$ & $-8.20^{* *}$ & $(-3.12)$ \\
\hline Education & $5.10^{* *}$ & $(18.69)$ & $5.10^{* *}$ & $(18.69)$ & $5.10^{* *}$ & $(18.69)$ & $5.10^{* *}$ & $(18.69)$ \\
\hline Household income/1000 & $5.35^{\star *}$ & (11.68) & $5.35^{* *}$ & $(11.68)$ & $5.35^{* *}$ & $(11.68)$ & $5.35^{* *}$ & $(11.68)$ \\
\hline Organizational membership & $7.29^{* *}$ & $(5.94)$ & $7.29^{* *}$ & $(5.94)$ & $7.29^{* *}$ & $(5.94)$ & $7.29^{* *}$ & $(5.94)$ \\
\hline Level 1 SD (residual) & \multicolumn{2}{|c|}{80.65} & \multicolumn{2}{|c|}{80.65} & \multicolumn{2}{|c|}{80.65} & \multicolumn{2}{|c|}{80.65} \\
\hline Level 2 SD (intercept) & \multicolumn{2}{|c|}{12.65} & \multicolumn{2}{|c|}{12.65} & \multicolumn{2}{|c|}{12.65} & \multicolumn{2}{|c|}{12.65} \\
\hline Level $1 \mathrm{~N}$ & \multicolumn{2}{|c|}{20,515} & \multicolumn{2}{|c|}{20,515} & \multicolumn{2}{|c|}{20,515} & \multicolumn{2}{|c|}{20,515} \\
\hline Level $2 \mathrm{~N}$ & \multicolumn{2}{|c|}{97} & \multicolumn{2}{|c|}{97} & \multicolumn{2}{|c|}{97} & \multicolumn{2}{|c|}{97} \\
\hline Deviance & \multicolumn{2}{|c|}{$238,493.6$} & \multicolumn{2}{|c|}{$238,493.6$} & \multicolumn{2}{|c|}{$238,493.6$} & \multicolumn{2}{|c|}{$238,493.6$} \\
\hline AIC & \multicolumn{2}{|c|}{$238,506.4$} & \multicolumn{2}{|c|}{$238,506.4$} & \multicolumn{2}{|c|}{$238,506.4$} & \multicolumn{2}{|c|}{$238,506.4$} \\
\hline
\end{tabular}

Note: Multilevel linear regressions; combined results from 5 multiply imputed data sets; un-standardized coefficients; $t$-values in parentheses; ${ }^{*} P<0.05,{ }^{*} P<0.01$; 
adherence to any particular faith. Individuals actively involved in religious life and strongly integrated into a religious community are more trusting than less integrated persons. Attending religious services at least once a month increases social trust by 16 plus/ minus 2 points on the trust scale. This is in line with the prediction of the religious network hypothesis ( $\mathrm{H} 2)$.

In order to test hypothesis $\mathrm{H} 2 \mathrm{~b}$, i.e. whether the effect of church attendance on social trust varies for different religious groups, we entered a multiplicative interaction term into the equation (see Table Al in the Appendix). Plotting the results in a marginal effect plot (cf. Brambor et al., 2005) shows that the positive effect of church attendance holds for all Christian groups but not for Muslims and the non-religious where in both cases the confidence intervals intersect zero (see Figure 1). The effect of church attendance on trust is strongest for Protestants, followed by members of small Christian groups and sects, and Catholics. Models M2 and M3 provide weak formal evidence that Protestant networks are more conducive to the generation of social trust than Catholic involvement, which points in the direction of hypothesis $\mathrm{H} 2 \mathrm{~b}$. However, the difference is only significant at 10 per cent and a global test suggests that the assumption of a group-specific effect of religious practice does not improve the model fit in a statistically significant way. Therefore, $\mathrm{H} 2 \mathrm{~b}$ is rejected and the interaction term is dropped from the subsequent models.

While only of minor theoretical importance for the present paper, the control variables at the individual level also show significant effects. As we would expect, higher-status people are more trusting-both education and income show significant positive effects. Organizational membership, too, is related to greater social trust as social capital theory suggests. Furthermore, trust first decreases and then increases with years of age. Finally, East Germans and foreigners are less trusting, while sex does not matter. Overall, there are no surprises here. With regard to substantive effect sizes and considering the empirical range of the predictor variables, education seems to have the greatest impact on trust-having higher tertiary education increases one's social trust by almost half a standard deviation $(9 \times 5=45$ points on the trust scale). However, the effect of regular attendance of religious services also seems to be quite substantial when compared to other factors. For instance, holding everything else constant, church attendance at least once a month has about the same effect on social trust as an increase of the monthly net household income by no less than 3000 Euros ( 16 versus $3 \times 5=15$ points).
In addition, going to church has an impact on trust twice as strong as organizational membership, which is often viewed as an important determinant of trust, as well as greater effects than either being East German or having foreign citizenship.

\section{Evidence at the Contextual Level}

Having tested the individual-level hypotheses, we now turn to the contextual hypotheses on religion and social trust. Indicators for the regions' Protestant cultural tradition, level of devoutness, and religious diversity as well as level- 2 controls are added to the random intercept model (see M1 Table 2). ${ }^{5}$ Although regional population shares of Protestants and Catholics in Germany are inversely related and testing one in essence implies testing the other (except maybe for parts of East Germany where people now are neither Protestant nor Catholic), in order to test the religious culture argument more fully, we also specified an additional model which included percentage Catholics instead of Protestants (M2). ${ }^{6}$

The inclusion of explanatory factors and controls on the contextual level improves the model fit. Results show that religious context generally has an independent effect on individual levels of social trust. However, it is rather small in size and not all religious properties of a given region are of equal importance. In fact, only a region's religious cultural tradition shows significant effects and is thus conducive to trust formation. While the coefficient for percentage Protestants in a region is positive in sign (M1), the one for percentage Catholics is negative (M2). Individuals in cultural contexts shaped by a religious tradition of Protestantism are generally more trusting than individuals in Catholic dominated contexts - their personal religious affiliation (or lack thereof) notwithstanding. Living in a hypothetical region with a Protestant population share of 100 per cent increases one's trust by 21 points on the scale, plus/minus 9 points. Conversely, living in a hypothetical 100 per cent Catholic region decreases one's trust in others by 19 plus/minus 10 points. Therefore, the religious culture hypothesis (H3) is supported by the empirical evidence.

With regard to regional levels of devoutness, however, no significant effect on social trust can be found. Whereas individual church attendance proved to be an important factor explaining social trust, living in a context with many regular churchgoers adds nothing to the explanation. In addition, and contrary to a widely held assumption, religious diversity poses no threat to social integration. Again, the respective 


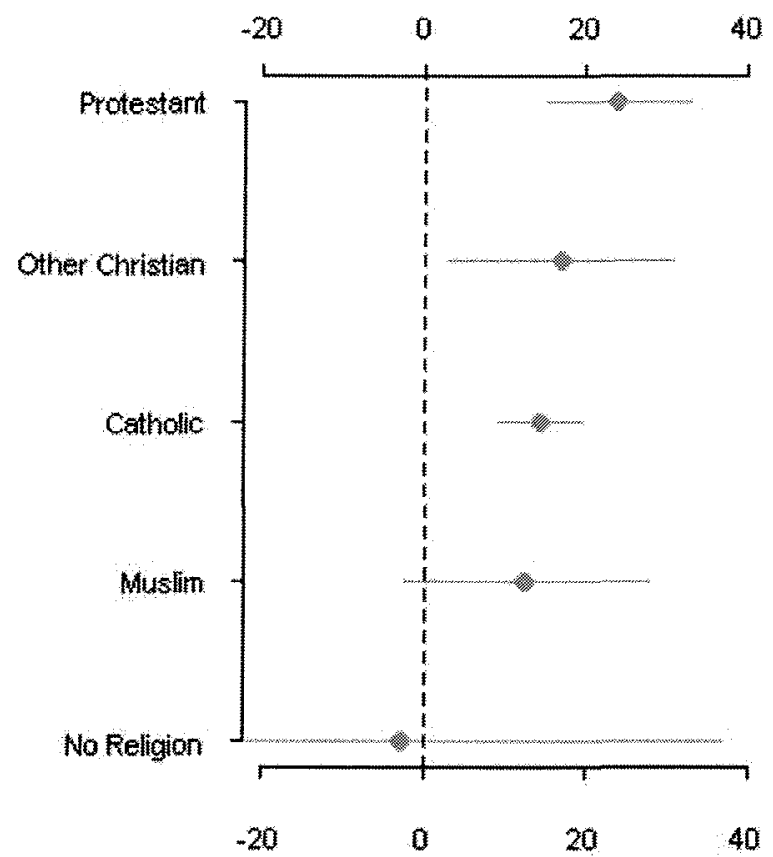

Figure 1 The effect of church attendance on social trust by religious group

Note: Marginal effects and 95\% confidence intervals of church attendance on social trust for different religious groups; based on the hierarchical model in Table A1 in the appendix; church attendance increases trust for all Christian groups, but not for Muslims or the non-religious; the strongest effect is for Protestants; however, the confidence intervals overlap, suggesting that the effect differences are not statistically reliable.

coefficients fail to reach statistical significance. Religious homogeneity does not seem to be a prerequisite for social trust that extends toward people in general. Neither the social control hypothesis ( $\mathrm{H} 4)$ nor the religious cleavage hypothesis (H5) holds up to empirical scrutiny.

There are, however, significant effects for some of the control variables. The better the economic performance in terms of GDP per capita in a region, the higher the level of social trust. According to the estimated coefficients, an increase in regional GDP per capita by 20.000 Euros has roughly the same effect as living in a region exclusively inhabited by Protestants $(20 \times 1=20$ versus 21 points on the scale). Other than religiously defined ethnic diversity shows a negative effect on trust and seems to matter more than religious diversity. However, the effect is only significant in model equation $\mathrm{Ml}$, as is the degree of urbanization in a region. ${ }^{7}$

\section{Further Analyses: Cross-Level Interactions}

So far, we have treated effects of individual religiosity and regional religious contexts as independent from one another. However, it may well be that individual religiosity has different effects on social trust formation depending on the context (cf. Ruiter and De Graaf, 2006; Scheepers et al., 2002). Likewise, it is conceivable that a given religious context does not influence all people's social attitudes the same way (cf. Borgonovi, 2008). In short, there may be cross-level interactions between individual and regional properties at work that should be further explored.

Therefore, we formed a total of four sets of multiplicative interaction terms and included them separately in equations for social trust. In the first set, individual church attendance is moderated by per cent Protestants in the region, overall devoutness, and religious diversity. The second set combines religious affiliation with per cent Protestant, the third relates the effect of religious affiliation to regional devoutness, and the fourth and final set consists of interaction terms between religious affiliation dummies and religious diversity. ${ }^{8}$

However, the impact of church attendance on social trust does not depend on any of the considered regional context variables. In addition, varying effects of religious affiliation, too, are determined neither by a region's religious tradition nor by its general level of devoutness. Again, likelihood-ratio tests suggest that there are no significant interaction effects. ${ }^{9}$

There is only one notable exception to these negative findings. There is a significant interaction between religious affiliation and the degree of religious diversity in a given region (see Table $\mathrm{A} 2$ in the Appendix). In particular, the effect of religious diversity on the social trust of Muslims differs significantly from the one found for Catholics, Protestants, and other Christians as well as from the effect for the non-religious (M1-M4). This suggests that the amount of trust Muslims place in people in general is determined by how heterogeneous in terms of religion their surrounding is. To be more precise, the direction of the sign indicates that for Muslims social trust in fact decreases with higher degrees of religious diversity. Therefore, religious diversity in a given region does matter for social trust, but is does not affect the trusting attitudes of each religious group in the same way.

The conditional effect plot in Figure 2 illustrates this point. Fixing all other factors constant to zero, the impact of religious diversity on social trust is more or less the same and virtually non-existent for adherents of all Christian faiths (i.e. Catholics, Protestants, and 
Table 2 Effects of individual religiosity and religious context on social trust (HLM)

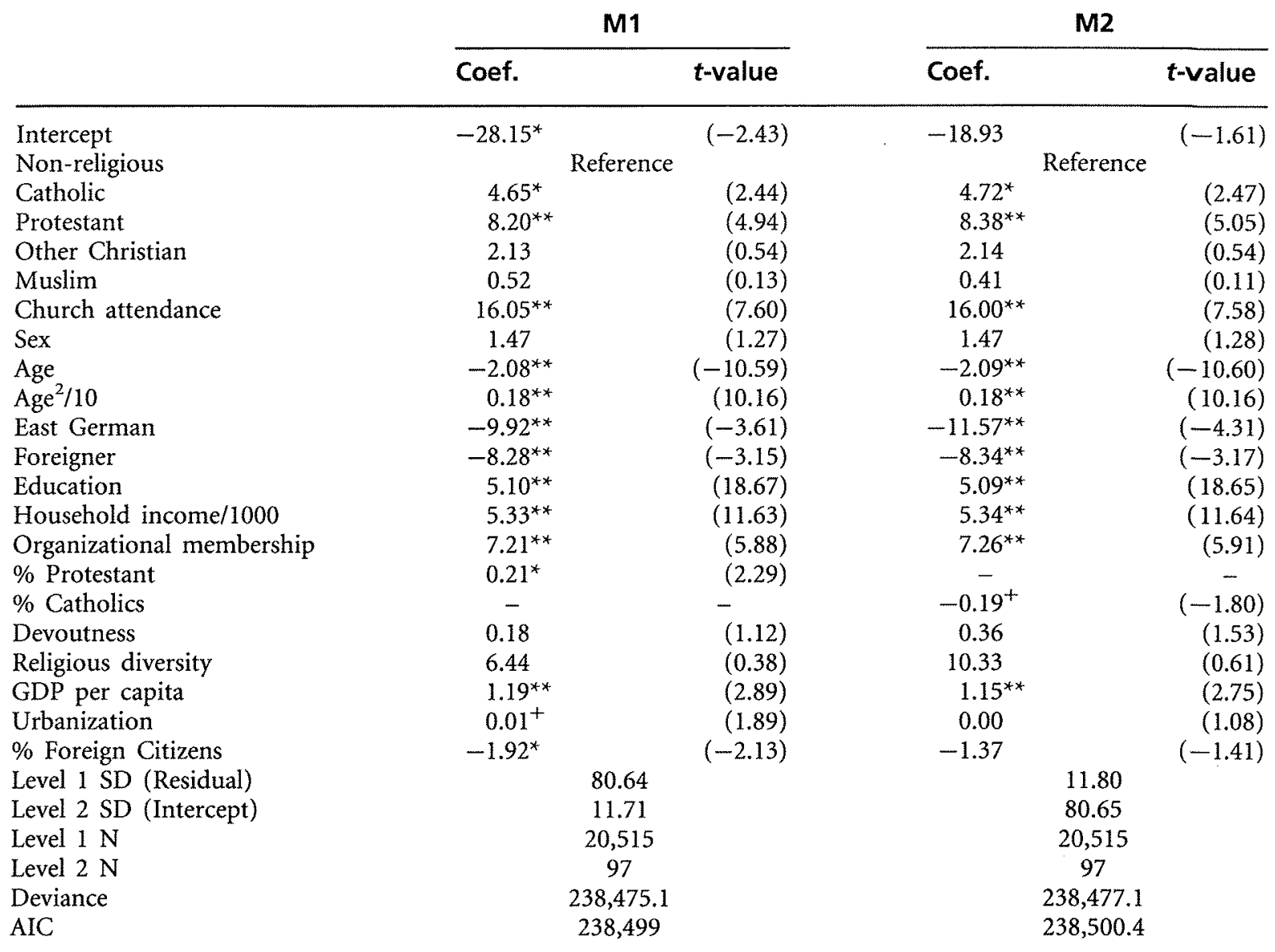

Note: Multilevel linear regressions; combined results from 5 multiply imputed data sets; un-standardized coefficients; $t$-values in parentheses; ${ }^{+} P<0.1$, ${ }^{*} P<0.05, * * p<0.01$.

smaller Christian groups), but differs markedly for Muslims, where it is clearly negative. In religiously homogeneous settings, Muslims are more trusting, while in religiously heterogeneous settings they are less trusting than adherents of Christian faiths.

At first sight, this finding may seem alarming, since it could indicate that religious diversity breeds feelings of distrust in Muslims and therefore poses a threat to social integration. However, plotting the marginal effects of being Muslim on social trust for different degrees of religious diversity renders the picture more clearly and shows what is really going on (see Figure 3). The general finding still holds-Muslims' social trust will be lower the more religiously diverse a region is. Nevertheless, as can be seen from the confidence intervals, the effect of being Muslim drops to statistical insignificance for regions with a religious heterogeneity measure between 0.58 and 0.74 on the Herfindahl-Index. However, these are exactly the regions where around 86 per cent-and therefore the vast majority-of all Muslims in the sample live. This is to say that in regions with larger shares of Muslims and thus higher religious diversity, Muslims in fact do not differ from non-religious people in terms of social trust toward the wider society.

\section{Conclusion}

In this paper, we aimed to examine the role of religion as a source of social capital. We went beyond existing work on the topic in three important respects. First, we focused on social trust as a dependent variable rather than the more common investigation of organizational membership and volunteering. Second, we concentrated on the religious landscape of Germany, which markedly differs from the frequently studied US and may be more indicative for other European societies. 


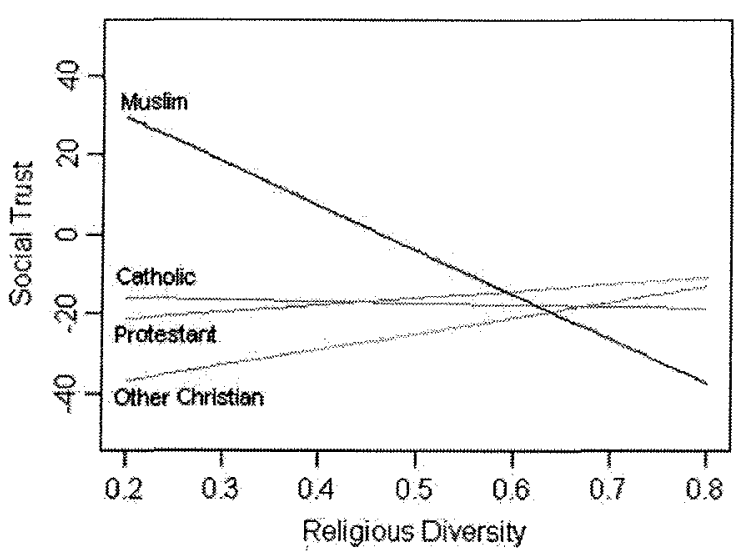

Figure 2 The effect of religious diversity on social trust by religious group

Note: Conditional effect plot of the impact of religious diversity on social trust for different religious groups; all other variables are held constant at zero; based on the hierarchical model in Table A2 in the appendix; religious diversity affects only the social trust of Muslims, not the trust of Christians; the higher the level of religious diversity within a region, the lower the social trust of Muslims.

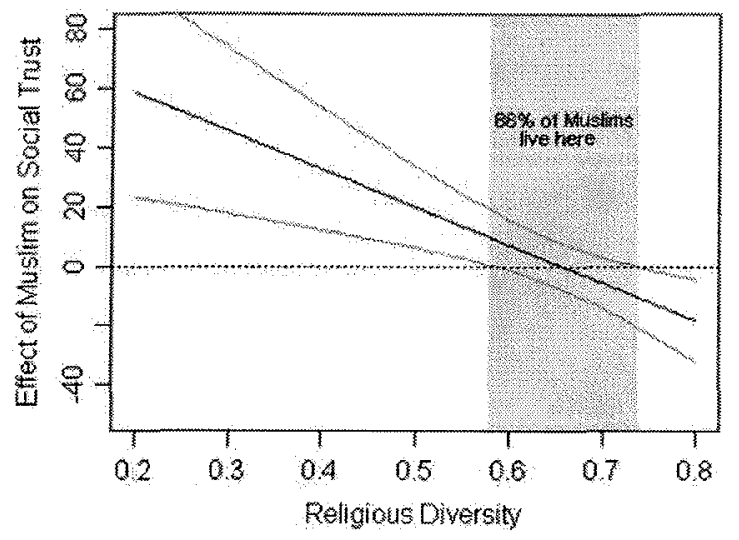

Figure 3 The effect of being Muslim on social trust by regional level of religious diversity

Note: Marginal effect and $95 \%$ confidence intervals of being Muslim on social trust for different levels of religious diversity; based on the hierarchical model in Table A2 in the Appendix; Muslims' trust decreases with regional levels of religious diversity; however, the effect of being Muslim turns statistically insignificant in regions between 0.58 and 0.74 on the diversity measure-that is where around 86 per cent of all Muslims in the sample live.

Third, the effect of individual religiosity as well as religious contexts by means of multilevel analysis was jointly tested.

The results suggest that both individual religiosity and regional religious contexts matter for the formation of social trust in Germany. In particular, a Protestant identity and a regional cultural tradition of Protestantism foster generalized social trust by extending the scope of moral communities beyond narrow in-groups toward people in general. In fact, one could speak of a double positive effect of Protestantism in the creation of social trust (cf. Lam, 2006). Findings on the trust-enhancing consequences of Protestantism in international comparisons (e.g. Bjørnskov, 2006; Delhey and Newton, 2005; Inglehart and Baker, 2000) are therefore confirmed for the German case. However, while in cross-national studies the positive impact on trust is almost impossible to separate from effects of political institutions (Delhey and Newton, 2005), the latter were controlled for in the specific sub-national research design. In this sense, the present result reveals the pristine trust-enhancing effect of Protestant religious culture. Conversely, social trust is less developed in Catholic-dominated regions. Moreover, although Catholic individuals are more trusting than non-religious, they do not differ from members of smaller Christian groups or Muslims. At same time, the notion that certain religious groups and especially religious minorities are distrustful of the wider society is not substantiated by empirical evidence.

Results further show that attendance of religious services is a powerful predictor for social trust in Germany. People who are actively involved in their religious community and therefore well integrated in religious networks display higher levels of trust. In fact this effect is stronger than the one found for organizational membership which is stressed by social capital theory (Putnam, 1993, 2000) and also more important than either being East German or having a foreign citizenship. However, no contextual effect for high regional levels of church attendance could be detected; the expectation that high church-attendance rates would deter delinquency and thereby encourage social trust (Stark and Bainbridge, 1996) was not met. Of course, these negative findings may very well be due to the chosen level of aggregation. Regions might still be too large to establish the effects of a devout surrounding. The present results might therefore be conservative and understate the true effects, which could possibly be observed at the level of local communities or neighborhoods. Future research should therefore attempt to experiment with these lower level contexts.

Finally, given the fact that Germany, like many European societies, is becoming increasingly more diverse, an interesting finding concerns the impact of religious diversity on social trust. While a first test showed no direct contextual effect of regional religious 
heterogeneity on social trust, further analyses allowing for cross-level interactions between regional and individual characteristics revealed an indirect impact of religious diversity. Indeed, religious diversity in a given region does have an effect on trust attitudes-but not for all religious groups. While there is no effect for Christian groups and the non-religious, Muslims' social trust is considerably reduced by religious heterogeneity. How can this finding be explained? A possible explanation could be that greater religious diversity in a given region is mainly due to larger Muslim communities, which in turn form strong in-groups and bonding forms of social capital by means of symbolic demarcation and withdrawal from the rest of society. At the same time, the increased visibility, which comes with greater group size, may spur conflict with the majority society and give rise to feelings and experiences of discrimination. Thus, Muslims in regions with a large Muslim community will be less trusting toward the wider society. However, one must not jump to conclusions here. Less trust does not indicate that members of the Muslim minority will in fact be distrustful toward the majority. Rather, the results suggest that Muslims for the most part simply do not differ from the non-religious when it comes to trust. Religious diversity thus need not jeopardize social integration.

\section{Notes}

1 The original coding in the GSOEP just uses four categories (instead of, say, seven as is often the case in other surveys) that cannot be treated as quasi-metric: 'never', 'less often', 'at least once a month', and 'at least once a week'. The author also experimented with the inclusion of dummies for each level. The effect of church attendance is not linear. Rather, the decisive cut point or treshold is 'at least once a month'; hence, decided to stick to the binary dummy-coding.

2 Of course, official data on adherents would be preferable. However, no such information exists on the regional level of the Raumordnungsregionen. Henkel (2001) only provides figures for Catholics and only for 1987. But correlating these reported Catholic shares with (unweighted) percentages calculated from the GSOEP yields a coefficient of $r=0.977$. This gives the confidence that the measure-while certainly not perfect-is still reasonable and the best possible.

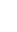

This measure of concentration is calculated by

$$
H I=1-\sum_{i=1}^{N} s_{i}^{2}
$$

where $N$ represents the number of different religious traditions in the region and $s_{i}$ is religion $i$ 's share of total adherents in the region. The index ranges from 0 to 1 , where 0 denotes complete religious homogeneity and 1 complete religious heterogeneity.

4 All contextual control measures are taken from the INKAR 2003 data released by the Federal Office for Building and Regional Planning. It should also be noted that we experimented with further controls on the regional level (e.g. income inequality, average level of education, and residential mobility). None of them seemed to matter. More importantly, however, their inclusion did not alter the results concerning the religious impact on trust.

5 Adding the religion variables at the contextual level separately to the model does not change the results.

6 However, due to issues of multicollinearity, including both measures at the same time was refrained from.

7 Separate models were estimated for East and West Germany, respectively. While this leads to smaller sample sizes at the contextual level and related problems of multicollinearity, the main findings remained robust. These results are available upon request.

8 This last model may be written as follows:

$$
\begin{aligned}
& \text { TRUST }_{i}= \gamma_{00}+\sum_{p=1}^{13} \gamma_{p 0} \text { INIVIDUALLEVELVARS }_{i j} \\
&+\sum_{q=1}^{\delta} \gamma_{q 0} \text { CONTEXTUALLEVELVARS }_{i j} \\
&+\gamma_{11} \text { CATHOLIC }_{i j} * \text { DIVERSITY } \\
&+\gamma_{21} \text { PROTESTANT }_{i j} * \text { DIVERSITY } \\
&+\gamma_{31} \text { OTHER }_{i j} * \text { DIVERSITY } \\
&+\gamma_{41} \text { MUSLIM }_{i j} * \text { DIVERSITY } \\
& j
\end{aligned}
$$

Note that this model specification is not a 'random slopes' model. That is to say, the coefficients of religious groups on the individual level $\left(\gamma_{10}, \gamma_{20}\right.$, $\left.\gamma_{30}, \gamma_{40}\right)$ do not vary randomly over regions $j$, therefore $u_{1 j}=u_{2 j}=u_{3 j}=u_{4 j}=0$. Through this simplification, we avoid having to include a 
whole number of additional variance components (the variances of the contextual deviations $\operatorname{Var}\left[u_{1} j\right.$, $\left.u_{2} j, u_{3} j, u_{4} j\right]=\tau_{1}{ }^{2}, \tau_{2}{ }^{2}, \tau_{3}{ }^{2}, \tau_{4}{ }^{2}$ as well as their covariances with the intercept $\operatorname{Cov}\left[u_{1 j}, u_{0 j} ; u_{2 j}, u_{0 j}\right.$; $\left.\left.u_{3 j}, u_{0 j} ; u_{4 j}, u_{0 j}\right]=\tau_{01}, \tau_{02}, \tau_{03}, \tau_{04}\right)$ in the model. This would considerably increase the model's complexity and lead to computational problems. Of course, this simplification involves the model theoretic assumption that regional differences in individual religious effects are completely accounted for by the religious context variables. However, given the primary theoretical interest at hand-whether the individual effects are moderated by religious contexts - this somewhat unrealistic assumption seems acceptable.

9 These results are available upon request from the author.

\section{Acknowledgements}

The author would like to thank the participants at these events as well as Peter Selb and two anonymous referees for their valuable comments and suggestions. This article was written as part of a research project on Worlds of Social Capital that was carried out within the framework of the Excellence Initiative of the German Research Foundation (in particular the Cluster of Excellence 'Cultural Foundations of Integration' and the Research Centre 'Volunteering and Social Capital'). Previous versions of this article were presented at the 8th International German Socio-Economic Panel User Conference at the Social Science Research Centre Berlin (July 2008), the workshop 'Religion@Society' at the University of Flensburg (November 2008), the workshop on 'Rational Choice Sociology: Theory and Empirical Applications' at Venice International University (Dezember 2008), and the workshop on 'Quantitative Research of Religion' at the Max Weber Center for Advanced Cultural and Social Studies, Erfurt (August/September 2009).

\section{References}

Alesina, A. and La Ferrara, E. (2000). Participation in heterogeneous communities. Quarterly Journal of Economics, 115, 847-904.

Anderson, C. J. and Paskeviciute, A. (2006). How ethnic and linguistic heterogeneity influence the prospects for civil society: a comparative study of citizenship behavior. Journal of Politics, 68, 783-802.
Bahovec, I., Potocnik, V. and Zrinscak, S. (2007). Religion and social capital: the diversity of European regions. In Adam, F. (Ed.), Social Capital and Governance. Berlin: Lit-Verlag, pp. 175-200.

Baier, C. J. and Wright, B. R. E. (2001). 'If you love me, keep my commandments': a meta-analysis of the effect of religion on crime. Journal of Research in Crime and Delinquency, 38, S3-S21.

Bainbridge, W. S. (1989). The religious ecology of deviance. American Sociological Review, 54, 288-295.

Banfield, E. C. (1958). The Moral Basis of a Backward Society. New York: Free Press.

Becker, P. E. and Dhingra, P. H. (2001). Religious involvement and volunteering: implications for civil society. Sociology of Religion, 62, 15-35.

Bjørnskov, C. (2006). Determinants of generalized trust: A cross-country comparison. Public Choice, $130,1-21$

Bjørnskov, C. (2008). Social trust and fractionalization: a possible reinterpretation. European Sociological Review, 24, 271-283.

Borgonovi, F. (2008). Divided we stand, united we fall: religious pluralism, giving, and volunteering. American Sociological Review, 73, 105-128.

Brambor, T., Roberts, W. and Golder, M. (2005). Understanding interaction models: improving empirical analyses. Political Analysis, 14, 63-82.

Buskens, V. and Raub, W. (2002). Embedded trust: control and learning. Advances in Group Processes, 19, 167-202.

Campbell, D. E. and Yonish, S. J. (2003). Religion and volunteering in America. In Smidt, C. E. (Ed.), Religion as Social Capital. Waco, TX: Baylor University Press, pp. 87-106.

Casanova, J. (2006). Einwanderung und der neue religiöse Pluralismus. Ein Vergleich zwischen der EU und den USA [Immigration and the new religious pluralism. A comparison of the $\mathrm{EU}$ and the USA]. Leviathan, 34, 182-207.

Coleman, J. S. (1988). Social capital in the creation of human capital. American Journal of Sociology, 94, 95-120.

Coleman, J. S. and Hoffer, T. (1987). Public and Private High Schools: The Impact of Communities. New York: Basic Books.

Cook, K. S. and Hardin, R. (2001). Norms of cooperativeness and networks of trust. In Hechter, M. and Opp, K.-D. (Eds.), Social Norms. New York: Russell Sage Foundation, pp. 327-347. 
De Hart, J. (2001). Religion and volunteering in the Netherlands. In Dekker, P. and Uslaner, E. M. (Eds.), Social Capital and Participation in Everyday Life. London: Routledge.

Delhey, J. and Newton, K. (2005). Predicting crossnational levels of social trust: global pattern or Nordic exceptionalism? European Sociological Review, 21, 311-327.

Durkheim, E. ([1897] 1951). Suicide. Glencoe, IL: Free Press.

Durkheim, E. ([1912] 1995). The Elementary Forms of the Religious Life. New York: Free Press.

Eisenstadt, S. N. (2000). Die Vielfalt der Moderne [Multiple Modernities]. Weilerswist: Velbrück Wissenschaf.

Finke, R. and Adamczyk, A. (2008). Cross-national moral beliefs: the influence of national religious context. Sociological Quarterly, 49, 617-652.

Freitag, M. (2003). Beyond Tocqueville: the origins of social capital in Switzerland. European Sociological Review, 19, 217-232.

Freitag, M. and Bühlmann, M. (2005). Politische Institutionen und die Entwicklung generalisierten Vertrauens. Ein internationaler Vergleich [Political institutions and the creation of generalized trust. An international comparison]. Politische Vierteljahresschrift, 46, 575-601.

Freitag, M. and Bühlmann, M. (2009). Crafting trust. The role of political institutions in a comparative perspective. Comparative Political Studies, 42, $1537-1566$.

Freitag, M. and Traunmüller, R. (2009). Spheres of trust. An empirical analysis of the foundations of particularised and generalised trust. European Journal of Political Research, 48, 782-803.

Fukuyama, F. (1995). Trust. The Social Virtues and the Creation of Prosperity. New York: Free Press.

Fukuyama, F. (2000). The Great Disruption: Human Nature and the Reconstruction of Social Order. New York: Free Press.

Gellner, E. (1981). Muslim Society. Cambridge: Cambridge University Press.

Gelman, A. and Hill, J. (2007). Data Analysis Using Regression and Multilevel/Hierarchical Models. Cambridge: Cambridge University Press.

Gerhards, J. (2006). Kulturelle Unterschiede in der europäischen Union: Ein Vergleich zwischen Mitgliedsländern, Beitrittskandidaten und der Türkei [Cultural Differences in the European Union: A Comparison of member states, accession candidates, and Turkey]. Wiesbaden: VS Verlag.
Greeley, A. (1997). Coleman revisited: religious structures as a source of social capital. The American Behavioral Scientist, 40, S587-S594.

Guiso, L., Sapienza, P. and Zingales, L. (2003). People's opium? Religion and economic attitudes. Journal of Monetary Economics, 50, 225-282.

Gundelach, B. and Traunmüller, R. (2010). Kulturelle Diversität und sozialer Zusammenhalt. Eine Mehrebenenanalyse zum Einfluss multikultureller Kontexte auf das Sozialkapital in den deutschen Regionen [Cultural diversity and social cohesion. A multilevel analysis of the effect of multicultural contexts on social capital in the German regions]. In Freitag, M. and Vatter, A. (Eds.), Subnational vergleichende Analysen für Deutschland. Institutionen, Staatstätigkeiten und politische Kulturen. München: Lit-Verlag, pp. 315-343.

Halman, L. and Petterson, T. (2003). Religion and social capital revisited. In Loek, $H$. and Riis, $O$. (Eds.), Religion in Secularizing Society. The European's Religion at the End of the 20th Century. Leiden: Brill, pp. 162-184.

Henkel, R. (2001). Atlas der Kirchen und der anderen Religionsgemeinschaften in Deutschland. Eine Religionsgeographie [Atlas of Churches and Religious Groups in Germany. A Geography of Religion]. Stuttgart: Kohlhammer.

Hooghe, M. and Stolle, D. (2003). Generating Social Capital. Civil Society and Institutions in Comparative Perspective. New York: Palgrave and MacMillan.

Hooghe, M., Reeskens, T., Stolle, D. and Trappers, A. (2009). Ethnic diversity and generalized trust in Europe: a cross-national multilevel study. Comparative Political Studies, 42, 198-223.

Huntington, S. P. (1996). Kampf der Kulturen. Die Neugestaltung der Weltpolitik im 21. Jahrhundert [The Clash of Civilizations and the Remaking of World Order]. München: Europa Verlag.

Inglehart, R. and Baker, W. E. (2000). Modernization, cultural change, and the persistence of traditional values. American Sociological Review, 65, 19-51.

King, G., Honaker, J., Joseph, A. and Scheve, K. (2001). Analyzing incomplete political science data: an alternative algorithm for multiple imputation. American Political Science Review, 95, 49-69.

König, W., Lüttinger, P. and Müller, W. (1988). A Comparative Analysis of the Development and Structure of Educational Systems. CASMIN-Project Mannheim: Institut für Sozialwissenschaften.

Kotler-Berkowitz, L. A. (2001). Religion and voting behaviour in Great Britain: a reassessment. British Journal of Political Science, 31, 523-554. 
La Porta, R., Lopez-de-Silanes, F., Shleifer, A. and Vishny, R. W. (1997). Trust in large organizations. American Economic Review, 87, 333-338.

Lam, P.-Y. (2002). As the flocks gather: how religion affects voluntary association participation. Journal for the Scientific Study of Religion, 41, 405-422.

Lam, P.-Y. (2006). Religion and civic culture: a crossnational study of voluntary association membership. Journal for the Social Scientific Study of Religion, 45, 177-193.

Leege, D. C. (1993). Religion and politics in theoretical perspective. In Leege, D. C. and Kellstedt, L. A. (Eds.), Rediscovering the Religious Factor in American Politics. Armonk: M.E. Sharpe, pp. 3-25.

Legewie, J. (2008). Zum Einfluss der regionalen Arbeitslosigkeit auf Einstellungen zur sozialen Gerechtigkeit [The effect of regional unemployment on social justice attitudes]. Kölner Zeitschrift für Soziologie und Sozialpsychologie, 60, 286-313.

Lijphart, A. (1971). Comparative politics and the comparative method. American Political Science Review, 65, 682-693.

McPherson, M., Smith-Lovin, L. and Cook, J. M. (2001). Birds of a feather: homophily in social networks. Annual Review of Sociology, 27, 415-444.

Meulemann, H. (2004). Religiosität: Die Persistenz eines Sonderfalls [Religiosity: the persistence of a special case]. In van Deth, J. W. (Ed.), Deutschland in Europa. Wiesbaden: VS Verlag, pp. 55-76.

Neller, K. (2008). Explaining social trust: what makes people trust their fellow citizens? In Meulemann, H. (Ed.), Social Capital in Europe: Similarity of Countries and Diversity of People? Multi-level analyses of the European Social Survey 2002. Leiden: Brill, pp. 103-133.

Norris, P. and Inglehart, R. (2004). Sacred and Secular. Religion and Politics Worldwide. Cambridge: Cambridge University Press.

Park, J. Z. and Smith, C. (2000). 'To whom much has been given...' religious capital and community voluntarism among churchgoing protestants. Journal for the Scientific Study of Religion, 39, 272-286.

Parsons, T. (1967). Sociological Theory and Modern Society. New York: Free Press.

Przeworski, A. and Teune, H. (1970). The Logic of Comparative Social Inquiry. New York: WileyInterscience.

Putnam, R. D. (1993). Making Democracy Work. Civic Traditions in Modern Italy. Princeton: Princeton University Press.
Putnam, R. D. (2000). Bowling Alone. The Collapse and Revival of American Community. New York: Simon and Schuste.

Putnam, R. D. (2007). E pluribus unum: diversity and community in the twenty-first century. The 2006 Johan Skytte Prize Lecture. Scandinavian Political Studies, 30, 137-174.

$\mathrm{R}$ Project. (2000). The $\mathrm{R}$ Project for statistical computing. www.r-project.org.

Raudenbush, S. W. and Bryk, A. S. (2002). Hierarchical Linear Models, 2nd edition Thousand Oaks: Sage.

Roßteutscher, S. (2008). Undemokratische Assoziationen [Un-democratic associations]. In Brodocz, A., Llanque, M. and Schaal, G. L. (Eds.), Bedrohungen der Demokratie. Wiesbaden: VS Verlag, pp. 61-76.

Roßteutscher, S. (2009). Religion, Zivilgesellschaft, Demokratie. Eine international vergleichende Studie zur Natur religiöser Märkte und der demokratischen Rolle religiöser Zivilgesellschaften [Religion, Civil Society, Democracy. An International Comparative Study on the Nature of Religious Markets and the Democratic Role of Religious Civil Societies]. BadenBaden: Nomos.

Ruiter, S. and De Graaf, N. D. (2006). National context, religiosity, and volunteering: results from 53 countries. American Sociological Review, 71, 191-221.

Sampson, R. J. (2001). Crime and public safety: insights from community-level perspectives on social capital. In Saegert, S., Thompson, J. P. and Warren, M. E. (Eds.), Social Capital and Poor Communities. New York: Russell Sage Foundation.

Scheepers, P., te Grotenhuis, M. and van der Slik, F. (2002). Education, religiosity and moral attitudes: explaining cross-national effect differences. Sociology of Religion, 63, 157-176.

Smidt, C. E. (2003). Religion as Social Capital. Producing the Common Good. Waco.

Snijders, T. A. B. and Bosker, R. J. (1999). Multilevel Analysis. An Introduction to Basic and Advanced Multilevel Modelling. London: Sage.

Snyder, R. (2001). Scaling down: the subnational comparative method. Studies in Comparative International Development, 36, 93-110.

Stark, R. (1996). Religion as context: hellfire and delinquency one more time. Sociology of Religion, 57, 163-173.

Stark, R. and Bainbridge, W. S. (1996). Religion. Deviance, and Social Control. New York: Routledge.

Sztompka, P. (1995). Vertrauen: Die Fehlende Ressource in der Postkommunistichen Gesellschaft [Trust: the missing resource in post-communist society]. In Nedelmann, B. (Ed.), Politische 
Institutionen in Wandel. (Kölner Zeitschrift für Soziologie und Sozialpsychologie, Sonderheft 35). Opladen: Westdeutscher, pp. 254-276.

Sztompka, P. (1999). Trust: A Sociological Theory. Cambridge: Cambridge University Press.

Tocqueville, A. de ([1862] 1954). Democracy in America. New York: Oxford University Press.

Traunmüller, R. (2009). Religion und Sozialintegration. Eine empirische Analyse der religiösen Grundlagen sozialen Kapitals [Religion and social integration. An empirical analysis of the religious foundations of social capital]. Berliner Journal für Soziologie, 19, 435-468.

Uslaner, E. M. (2002a). Religion and civic engagement in Canada and the United States. Journal for the Social Scientific Study of Religion, 41, 239-254.

Uslaner, E. M. (2002b). The Moral Foundations of Trust. Cambridge: Cambridge University Press.

Verba, S., Schlozman, K. L. and Brady, H. (1995). Voice and Equality: Civic Voluntarism in American Politics. Cambridge: Harvard University Press.

Wagner, G. G., Frick, J. R. and Schupp, J. (2007). The German Socio-Economic Panel Study (SOEP) scope, evolution and enhancements. Schmollers Jahrbuch, 127, 139-169.

Weber, M. ([1920] 1988). Gesammelte Aufsätze zur Religionssoziologie I [Collected Essays on the Sociology of Religion I]. Tübingen: Mohr-Siebeck.

Welch, M. R., Sikkink, D., Sartain, E. and Bond, C. (2004). Trust in god and trust in man: the ambivalent role of religion in shaping dimensions of social trust. Journal for the Social Scientific Study of Religion, 43, 317-343.

Wilson, J. and Janoski, T. (1995). The contribution of religion to volunteer work. Sociology of Religion, 56, 137-152.
Wolf, C. (1999). Religiöse Pluralisierung in der Bundesrepublik Deutschland [Religious pluralization in Germany]. In Friedrichs, J. and Jagodzinski, W. (Eds.), Soziale Integration. (Kölner Zeitschrift für Soziologie und Sozialpsychologie, Sonderheft 39). Opladen: Westdeutscher, pp. 320-349.

Wrightsman, L. S. (1992). Assumptions about Human Nature. Implications for Researchers and Practitioners. Newbury Park, CA: Sage.

Wuthnow, R. (1990). Religion and the voluntary spirit in the United States: mapping the terrain. In Wuthnow, R. and Hodgkinson, V. A. (Eds.), Faith and Philanthropy in America: Exploring the Role of Religion in America's Voluntary Sector. San Francisco: Jossey-Bass.

Wuthnow, R. (1999). Mobilizing civic engagement: the changing impact of religious involvement. In Skocpol, T. and Fiorina, M. P. (Eds.), Civic Engagement in American Democracy. Washington, DC: Brookings Institution Press, pp. 331-363.

Yeung, A. B. (2004). An intricate triangle - religiosity, volunteering, and social capital: The European perspective, the case of Finland. Nonprofit and Voluntary Sector Quarterly, 33, 401-422.

\section{Author's Address}

Richard Traunmüller, Department of Politics and Management, University of Konstanz, P.O. Box 84, 78457 Konstanz, Germany. Email: richard .traunmueller@uni-konstanz.de 


\section{Appendix}

Table A1 Interaction effects of individual religiosity on social trust (HLM)

\begin{tabular}{|c|c|c|c|c|c|c|c|c|}
\hline & \multicolumn{2}{|c|}{ M1 } & \multicolumn{2}{|c|}{ M2 } & \multicolumn{2}{|c|}{ M3 } & \multicolumn{2}{|c|}{ M4 } \\
\hline & Coef. & $t$-value & Coef. & $t$-value & Coef. & $t$-value & Coef. & $t$-value \\
\hline Intercept & $11.15^{*}$ & $(2.05)$ & $15.80^{* *}$ & $(3.00)$ & $19.14^{* *}$ & (3.65) & $13.03^{+}$ & $(1.86)$ \\
\hline Non-religious & \multicolumn{2}{|c|}{ Reference } & $-4.65^{*}$ & $(-2.43)$ & $-7.99^{* *}$ & $(-4.80)$ & -1.88 & $(-0.38)$ \\
\hline Catholic & $4.65^{*}$ & (2.43) & \multicolumn{2}{|c|}{ Reference } & $-3.33^{*}$ & $(-1.99)$ & 2.78 & $(0.58)$ \\
\hline Protestant & $7.99^{* *}$ & $(4.80)$ & $3.33^{*}$ & $(1.99)$ & \multicolumn{2}{|c|}{ Reference } & 6.11 & (1.26) \\
\hline Other Christian & 1.88 & $(0.38)$ & -2.78 & $(-0.58)$ & -6.11 & $(-1.23)$ & \multicolumn{2}{|c|}{ Reference } \\
\hline Muslim & 0.87 & $(0.21)$ & -3.78 & $(-0.95)$ & $-7.11^{+}$ & $(-1.76)$ & -1.00 & $(-0.18)$ \\
\hline Church attendance & -3.52 & $(-0.17)$ & $14.36^{* x}$ & (5.40) & $23.51^{\star *}$ & $(5.06)$ & $16.62^{\star}$ & (2.35) \\
\hline Non-religious $\times$ church attendance & \multicolumn{2}{|c|}{ Reference } & -17.88 & $(-0.88)$ & -27.02 & $(-1.31)$ & -20.13 & $(-0.94)$ \\
\hline Catholic $\times$ church attendance & 17.88 & $(0.88)$ & \multicolumn{2}{|c|}{ Reference } & $-9.14^{+}$ & $(-1.72)$ & -2.25 & $(-0.30)$ \\
\hline Protestant $\times$ church attendance & 27.02 & (1.31) & $9.14^{+}$ & $(1.72)$ & \multicolumn{2}{|c|}{ Reference } & 6.89 & $(0.81)$ \\
\hline Other Christian $\times$ church attendance & 20.13 & $(0.94)$ & 2.25 & $(0.30)$ & -6.89 & $(-0.81)$ & \multicolumn{2}{|c|}{ Reference } \\
\hline Muslim $\times$ church attendance & 16.19 & $(0.75)$ & -1.68 & $(-0.21)$ & -10.83 & $(-1.20)$ & -3.94 & $(-0.38)$ \\
\hline Level 1 controls & \multicolumn{2}{|c|}{ yes } & & \multicolumn{2}{|c|}{ ves } & \multicolumn{2}{|c|}{ ves } \\
\hline Level 1 SD (residual & \multirow{2}{*}{\multicolumn{2}{|c|}{$\begin{array}{l}80.65 \\
12.65\end{array}$}} & & & & & \multirow{2}{*}{\multicolumn{2}{|c|}{$\begin{array}{l}80.65 \\
12.65\end{array}$}} \\
\hline Level 2 SD (intercept) & & & \multicolumn{2}{|c|}{12.65} & \multicolumn{2}{|c|}{$\begin{array}{l}80.65 \\
12.65\end{array}$} & & \\
\hline Level $1 \mathrm{~N}$ & \multicolumn{2}{|c|}{20,515} & \multirow{2}{*}{\multicolumn{2}{|c|}{$\begin{array}{c}20,515 \\
97\end{array}$}} & \multicolumn{2}{|c|}{20,515} & \multicolumn{2}{|c|}{20,515} \\
\hline Level 2N & \multirow{2}{*}{\multicolumn{2}{|c|}{$\begin{array}{c}97 \\
238,489.3\end{array}$}} & & & \multirow{2}{*}{\multicolumn{2}{|c|}{$\begin{array}{c}97 \\
238,489.3\end{array}$}} & \multicolumn{2}{|c|}{97} \\
\hline Deviance & & & & & & \multirow{2}{*}{\multicolumn{2}{|c|}{$\begin{array}{l}238,409.3 \\
238,485.2\end{array}$}} \\
\hline AIC & \multicolumn{2}{|c|}{$238,485.2$} & \multicolumn{2}{|c|}{$238,485.2$} & \multicolumn{2}{|c|}{$238,485.2$} & & \\
\hline
\end{tabular}

Note: Multilevel linear regressions; combined results from 5 multiply imputed data sets; un-standardized coefficients; $t$-values in parentheses; ${ }^{+} P<0.1,{ }^{*} P<0.05,{ }^{*} P<0.01 ;$ model includes controls for sex, age, age squared, East German, foreigner, education, household income, and organizational membership. 
Table A2 Religious cross-level interactions on social trust (HLM)

\begin{tabular}{|c|c|c|c|c|c|c|c|c|}
\hline & \multicolumn{2}{|c|}{ M1 } & \multicolumn{2}{|c|}{ M2 } & \multicolumn{2}{|c|}{ M3 } & \multicolumn{2}{|c|}{ M4 } \\
\hline & Coef. & t-value & Coef. & $t$-value & Coef. & $t$-value & Coef. & $t$-value \\
\hline Intercept & $-32.41^{* *}$ & $(-2.65)$ & -15.14 & $(-1.17)$ & $-24.61^{+}$ & $(-1.94)$ & $-44.60^{+}$ & $(-1.83)$ \\
\hline Level 1 controls & \multicolumn{2}{|c|}{ yes } & \multicolumn{2}{|c|}{ yes } & \multicolumn{2}{|c|}{ yes } & \multicolumn{2}{|c|}{ yes } \\
\hline Non-religious & \multicolumn{2}{|c|}{ Reference } & $-17.27^{+}$ & $(-1.90)$ & -7.80 & $(-1.08)$ & 12.19 & $(0.55)$ \\
\hline Catholic & $17.27^{+}$ & $(1.90)$ & \multicolumn{2}{|c|}{ Reference } & 9.47 & $(1.06)$ & 29.46 & $(1.32)$ \\
\hline Protestant & 7.80 & (1.08) & -9.47 & $(-1.06)$ & \multicolumn{2}{|c|}{ Reference } & 19.99 & $(0.90)$ \\
\hline Other Christian & -12.19 & $(-0.55)$ & -29.46 & $(-1.32)$ & -19.99 & $(-0.90)$ & \multicolumn{2}{|c|}{ Reference } \\
\hline Muslim & $84.06^{* *}$ & $(3.23)$ & $66.79^{* *}$ & $(2.57)$ & $76.25^{\star *}$ & $(2.94)$ & $96.24^{* *}$ & $(2.87)$ \\
\hline Church attendance & $16.03^{\star *}$ & $\quad(7.59)$ & $16.03^{* *}$ & $(7.59)$ & $16.03^{* *}$ & $(7.59)$ & $16.03^{* *}$ & $(7.59)$ \\
\hline$\%$ Protestant & $0.21^{*}$ & $(2.27)$ & $0.21^{\star}$ & $(2.27)$ & $0.21^{*}$ & $(2.27)$ & $0.21^{\star}$ & $(2.27)$ \\
\hline Devoutness & 12.03 & $(0.71)$ & 12.03 & $(0.71)$ & 12.03 & $(0.71)$ & 12.03 & $(0.71)$ \\
\hline Religious diversity & 16.71 & $(0.86)$ & -4.20 & $(-0.22)$ & 17.31 & $(0.91)$ & 39.38 & $(1.03)$ \\
\hline Non-religious $\times$ religious diversity & \multicolumn{2}{|c|}{ Reference } & 20.91 & $(1.38)$ & -0.60 & $(-0.05)$ & -22.67 & $(-0.63)$ \\
\hline Catholic $\times$ religious diversity & -20.91 & $(-1.38)$ & \multicolumn{2}{|c|}{ Reference } & -21.51 & $(-1.47)$ & -43.58 & $(-1.22)$ \\
\hline Protestant $\times$ religious diversity & 0.60 & $(0.05)$ & 21.51 & $(1.47)$ & \multicolumn{2}{|c|}{ Reference } & -22.07 & $(-0.62)$ \\
\hline Other Christian $\times$ religious diversity & 22.67 & $(0.63)$ & 43.58 & $(1.22)$ & 22.07 & $(0.62)$ & \multicolumn{2}{|c|}{ Reference } \\
\hline Muslim $\times$ religious diversity & \multicolumn{4}{|c|}{$-127.83^{* *}(-3.23)-106.92^{* *}(-2.71)$} & \multicolumn{4}{|c|}{$-128.43^{* *}(-3.27)-150.50^{* *}(-2.91)$} \\
\hline Level 2 controls & \multicolumn{2}{|c|}{ yes } & \multicolumn{2}{|c|}{ yes } & \multicolumn{2}{|c|}{ yes } & \multicolumn{2}{|c|}{ Yes } \\
\hline Level 1 SD (residual) & \multicolumn{2}{|c|}{80.62} & \multicolumn{2}{|c|}{80.62} & \multicolumn{2}{|c|}{80.62} & \multicolumn{2}{|c|}{80.62} \\
\hline Level 2 SD (intercept) & \multicolumn{2}{|c|}{11.86} & \multicolumn{2}{|c|}{11.86} & \multicolumn{2}{|c|}{11.86} & \multicolumn{2}{|c|}{11.86} \\
\hline Level $1 \mathrm{~N}$ & \multicolumn{2}{|c|}{20,515} & 20,5 & & 205 & & 20,5 & 15 \\
\hline Level $2 \mathrm{~N}$ & 97 & & 97 & & 97 & & 97 & \\
\hline Deviance & 238,40 & 61.8 & 238,4 & 61.8 & 238,4 & 61.8 & 238,46 & 61.8 \\
\hline AIC & 238,4 & 61.4 & 238,4 & 61.4 & 238,4 & 61.4 & 238,46 & 61.4 \\
\hline
\end{tabular}

Note: Multilevel linear regressions; combined results from 5 multiply imputed data sets; un-standardized coefficients; $t$-values in parentheses; ${ }^{+} P<0.1,{ }^{*} P<0.05,{ }^{*} P<0.01 ;$ model includes controls for sex, age, age squared, East German, foreigner, education, household income, organizational membership, GDP per capita, urbanization, and percentage foreign citizens. 